\begin{tabular}{|l|c|c|c|r|}
\hline $\begin{array}{l}\text { Cuadernos de Investigación Geográfica } \\
\text { Geographical Research Letters }\end{array}$ & 2017 & N $^{\circ} 43(1)$ & pp. 119-140 & $\begin{array}{r}\text { ISSN 0211-6820 } \\
\text { eISSN 1697-9540 }\end{array}$ \\
\hline
\end{tabular}

\title{
SOIL EROSION IN SLOPING VINEYARDS UNDER CONVENTIONAL AND ORGANIC LAND USE MANAGEMENTS (SAAR-MOSEL VALLEY, GERMANY)
}

\author{
M. KIRCHHOFF ${ }^{*}$, J. RODRIGO-COMINO ${ }^{1,2}$, M. SEEGER ${ }^{1}$, J.B. RIES ${ }^{1}$ \\ ${ }^{1}$ Department of Physical Geography, Trier University, D-54286 Trier, Germany. \\ ${ }^{2}$ Instituto de Geomorfología y Suelos, University of Málaga, 29071, Málaga, Spain.
}

\begin{abstract}
German vineyards are one of the land uses most prone to soil erosion. Due to their placement on mainly steep slopes and non-conservative cultivation practices, runoff and soil loss are a serious problem for wine growers. In the Saar-Mosel valley (Rhineland-Palatinate, Germany), there is a tendency towards organic management of vineyards with protective grass cover in the inter-rows. Since there is a lack of information about organicconventional tillage in German vineyards related to soil erosion processes, this study presents a comparison between these two soil management practices. For this purpose, 22 rainfall simulations were performed as well as a mediumterm monitoring by using 4-paired Gerlach troughs in two experimental sites in the Saar-Mosel valley. The mean simulated runoff coefficient and suspended sediment load in conventional vineyards amounted up to $23.3 \%$ and $33.75 \mathrm{~g} \mathrm{~m}^{-2}$, respectively. In the organic site, runoff and soil loss were only recorded in one out of the 11 simulations. Runoff and sediment was collected in the Gerlach troughs for 33 natural rainfall events. In the conventional vineyard, the total measured soil loss was $3314.63 \mathrm{~g} \mathrm{~m}^{-1}$ and $6503.77 \mathrm{~g} \mathrm{~m}^{-1}$ and total runoff volumes were $105.52 \mathrm{~L} \mathrm{~m}^{-1}$ and $172.58 \mathrm{~L} \mathrm{~m}^{-1}$. In the organic site, total soil losses reached $143.16 \mathrm{~g} \mathrm{~m}^{-1}$ and $258.89 \mathrm{~g} \mathrm{~m}^{-1}$ and total runoff was $21.65 \mathrm{~L} \mathrm{~m}^{-1}$ and $12.69 \mathrm{~L} \mathrm{~m}^{-1}$. When soil loss was measured without corresponding runoff or precipitation, soil erosion was activated by tillage or trampling. Finally, the conventional vineyard showed a higher variability in soil loss and runoff suggesting less predictable results.
\end{abstract}

Erosión del suelo en viñas cultivadas en pendiente bajo sistemas de gestión convencional y orgánica (Valle de Saar-Mosela, Alemania)

RESUMEN. Las viñas alemanas constituyen uno de los usos del suelo más susceptibles a la erosión. Debido a su emplazamiento sobre fuertes pendientes y a prácticas agrícolas poco sostenibles, la escorrentía y las pérdidas de suelo son un grave problema para los viticultores. En el valle del Sarre-Mosela (RenaniaPalatinado, Alemania) existe actualmente una tendencia al manejo sostenible 
del suelo con medidas de protección como el uso de una cubierta vegetal entre calles. Dada la carencia de información sobre las diferencias erosivas entre laboreos convencionales y de conservación en las viñas alemanas, en este estudio comparamos ambos tipos de laboreo. Para ello, en dos parcelas experimentales localizadas en el Valle del Sarre-Mosela se realizaron 22 simulaciones de lluvia y se recogió el sedimento de 4 cajas Gerlach. Los resultados de las pruebas de simulación de lluvia en las viñas con laboreo convencional mostraron un coeficiente de escorrentía del $23.3 \%$ y pérdidas de suelo de $33.75 \mathrm{~g} \mathrm{~m}^{-2}$. En la viña con laboreo de conservación, solo en una de las once simulaciones de lluvia se registró escorrentía y pérdida de suelo. Un total de 33 eventos naturales de lluvia fueron monitoreados con las cajas Gerlach. En las viñas con laboreo convencional las tasas de pérdida de suelo oscilaron entre 3314.63 $g m^{-1}$ y $6503.77 \mathrm{~g} \mathrm{~m}^{-1}$ y el volumen de escorrentía superficial entre $172.58 \mathrm{~L}$ $m^{-1}$ y $105.52 \mathrm{~L} \mathrm{~m}^{-1}$. En cambio, en la parcela con laboreo de conservación los resultados de pérdida de suelo oscilaron entre $143.16 \mathrm{~g} \mathrm{~m}^{-1}$ y $258.89 \mathrm{~g} \mathrm{~m}^{-1}, y$ entre $105.52 \mathrm{~L} \mathrm{~m}^{-1}$ y $172.58 \mathrm{~L} \mathrm{~m}^{-1}$ el volumen de escorrentía. Se observó que el laboreo y las pisadas de los viticultores fueron la causa principal que generó sedimento en los eventos sin registro de escorrentía. Por último, se observó que el manejo convencional generó unos resultados más variables e impredecibles que el laboreo de conservación.

Key words: soil erosion, organic vineyards, conventional vineyards, rainfall simulation, Gerlach trough.

Palabras clave: erosión, viñedo ecológico, viñedo convencional, simulación de lluvia, caja Gerlach.

Received: 22 November 2016 Accepted: 26 January 2016

* Corresponding author: M. Kirchhoff, Department of Physical Geography, Trier University, D-54286 Trier, Germany. E-mail address: s6makirc@uni-trier.de

\section{Introduction}

Soils are one of the most important components of biological, hydrological and geochemical cycles (Brevik et al., 2015; Keesstra et al., 2012, 2016a) and thus are in a state of constant change and evolution (Simonson, 1959; Corbane et al., 2012; Novák et al., 2014). Transport of matter and energy through the soil (Bryan, 2000; Blum, 2005; Kovacs, 2012) is just one example of processes that show the dynamics of the pedosphere in part influenced by natural factors (Smith et al., 2015). Important biological and hydrological functions provided by the soil are at risk due to an anthropogenic overuse or mismanagement (Tarolli and Sofia, 2016; Tarolli, 2016), which can lead to erosion and degradation of soil, and the partial destruction of soil functions and resources (Costantini et al., 2015; Cerdà et al., 2016). 
Vineyards are one of the land uses most prone to be heavily eroded by water (Prosdocimi et al., 2016a; Rodrigo Comino et al., 2016a; Cerdan et al., 2010) due to their oftentimes placement on steep slopes and non-conservative cultivation practices such as keeping the inter-rows bare during the whole year (Arnáez et al., 2007; Prosdocimi et al., 2016b). Moreover, frequent use of heavy machinery (e.g. tractors) leads to a compaction of the top and subsurface layers in the ruts (Ferrero et al., 2005; Rodrigo Comino et al., 2015; 2016c; 2016d). Rill erosion can be predominant over sheet erosion depending on the spatial scale and the environmental conditions, as shown by Quiquerez et al. (2008, 2014) and Chevigny et al. (2014). They concluded that over $30 \%$ of fine material can be eroded with soil lowering up to 0.5 to $2 \mathrm{~mm} \mathrm{yr}^{-1}$, leading to a reduced soil fertility and sustainability. In the Penèdes region from northeast Spain and on Sicily in Italy, it was demonstrated that the cost of soil erosion in vineyards could amount to a great part of the final income from the sale of the grape production, as a result of the damaged infrastructures and cost associated to broad-based terraces, drainage channels or filling of ephemeral gullies, and washed off nutrients needing to be replaced (MartínezCasasnovas and Ramos, 2006; Galati et al., 2015).

There are numerous types of management practices to be conducted in vineyards, concerning the soil cover in the inter-rows and rows. The soil can be kept bare through tillage or chemical weeding (no tillage necessary), while the most common and cheapest alternative is a permanent grass cover or the application of straw mulches (García Díaz et al., 2016; Morvan et al., 2014; Prosdocimi et al., 2016b). In semiarid areas, farmers keep the soils bare mostly to avoid the competition for water and nutrients by weeds (Ramos and MartínezCasasnovas, 2006; Raclot et al., 2009) or to improve the accessibility of the vineyard.

Organic farming in vineyards aims towards a higher sustainability and biodiversity of the soil, including soil fauna (Reinecke et al., 2008; Bruggisser et al., 2010) or microbial biomass (Probst et al., 2008). Grass cover was shown to reduce soil and nutrient losses compared to tilled soils (Biddoccu et al., 2016; Morvan et al., 2014; Rodrigo Comino et al., 2016a, 2016b). Mulching is another possibility to reduce runoff and erosion, where cut grass, straw or other organic materials (Hueso-González et al., 2014, 2016, 2017) form a thin protective blanket over the bare soil (Stigter, 1984). A similar method is the use of geotextiles to shield the soil from runoff and provide favourable soil moisture conditions (Kertész et al., 2007; Giménez-Morera et al., 2010), but is more expensive. Soil conservation measures proved to reduce soil and nutrient losses with no tillage (Keesstra et al., 2016b; Cerdà et al., 2016).

German vineyards are located close to the European northern boundary for winegrowing above which pedoclimatic conditions do not allow grape ripening due to the low temperatures (Ashenfelter and Storchmann, 2010a, 2010b; Koch et al., 2013). However, the introduction of new plantations with conventional management and the use of heavy machinery are enhancing land degradation processes such as soil erosion, which can be observed at hillslope and pedon scales. Some consequences related to soil erosion processes in some studied conventional managements (Hacisalihoglu, 2007; Richter, 1980, Rodrigo Comino et al., 2015, 2016c) are the high disturbance of the soil profile during the initial plantation, rill and ephemeral gully formations due to wheel traffic impacts for tilling 
and ploughing, and high runoff and soil loss rates. However, there is currently a lack of information about quantifications of soil erosion and hydrological processes in short- and medium-term periods and its mechanisms at intra-plot scale compared to other managements. Therefore, the aim of this study is to compare the rates of runoff and soil losses in a context of simulated events (rainfall simulations) and natural events (in open plots) with different land managements such as conventional (bare soils) and organic (grass cover) farming.

\section{Materials and methods}

\subsection{Study area}

The study site is located close to the village of Kanzem (Fig. 1) in the Saar-Mosel Valley (49.6667 N; 6.5756 E, Rhineland-Palatinate, Germany). The two chosen vineyards were both planted with the Riesling grapevines variety and situated next to each other, but one being conventionally and the other organically managed.

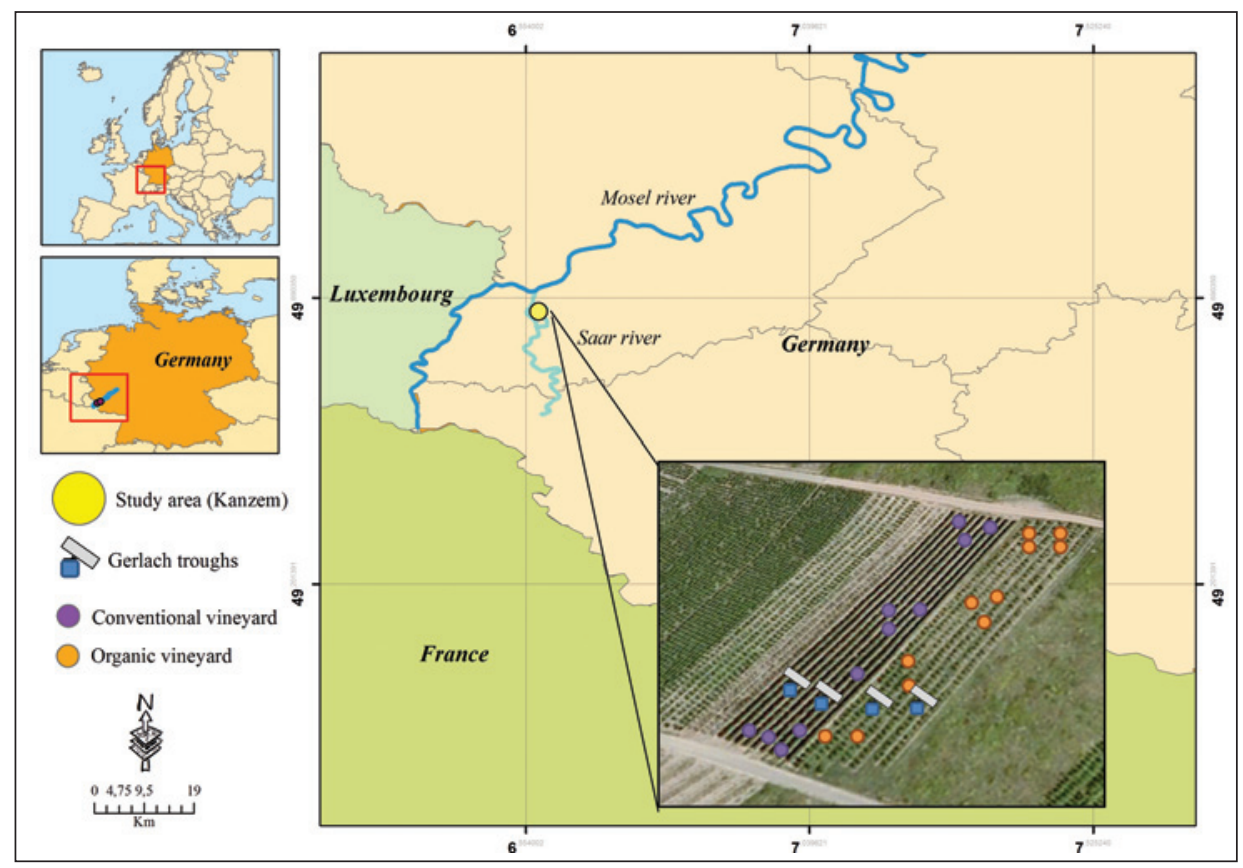

Figure 1. Study area.

The average air temperature is $14.1^{\circ} \mathrm{C}$, the total annual rainfall is $749 \mathrm{~mm}$ (http:// www.wetter.rlp.de). The vineyards are located at an altitude between 150-250 m, with the slope ranging from $17^{\circ}$ to $35^{\circ}$. The soils of both vineyards can be described as leptichumic Regosols (IUSS Working Group WRB, 2014). They show a higher sand content in the organic $(60.9 \%)$ than in the conventional vineyard $(49 \%)$. The latter is also characterized by high silt contents $(40.4 \%)$. The organic matter content is higher in 
the conventional vineyard $(10.6 \%)$ than in the soils with organic management $(5.4 \%)$. The organic vineyard is cultivated with old vines on single poles planted in 1967, the conventionally managed vines are about 30 years old.

Organic viticulture is a type of management that aims at preserving soil functions, biodiversity and vegetation cover on the vineyard without using synthetic fertilizers or herbicides/pesticides and is regulated by certifiers accredited to the European Convention (regulation-EU-No 203/2012). The soil tillage in the studied organic vineyard is mainly conducted from the end of March until May as well as in summer before the harvest. Mechanized measures include harrowing, mulching and grubbing, while hoeing under the rows and grass cutting are performed without heavy machinery but by hand or with a brush-cutter. Machines used are a narrow tractor with an attached mower or alternatively rotary harrows, a grubber with either sub-soilers or wing shares as well as a hand-operated crawler with a shredder. Those practices are taken to loosen the soil, mineralize nutrients at growth or blossoming of the vine, minimizing drought stress, breaking capillaries, removing rival plants and preparing the seedbed for revegetation between the rows. The soil tillage varies from year to year depending on the weather (between 5-8 times from March to August, mechanized measures). The tillage practices in the conventional vineyard are mainly done by mechanical tilling and ploughing before and after grape harvesting in the first $20 \mathrm{~cm}$ of depth (spring and early autumn). The presence of mulch and grass covers is common, as well as the use of slates covering the soil to protect the surface against the rain splash effect and cold temperatures. Finally, herbicides and fungicides are applied during spring and summer, spraying on several occasions.

\subsection{Methods}

\subsubsection{Small portable rainfall simulation and plots}

We used a modified nozzle-type rainfall simulator (Cerdà, 1999). A detailed description can be found in Iserloh et al. (2012). A nozzle Lechler 460608 was used, spraying from $2 \mathrm{~m}$ height. The tested plots were circular with a diameter about $60 \mathrm{~cm}$ and a total area of approximately $0.28 \mathrm{~m}^{2}$. A reproducible artificial rainfall is set by managing a flow control. This small portable rainfall simulator was always calibrated for a rainfall intensity of $40 \mathrm{~mm} \mathrm{~h}^{-1}$ to allow comparing both areas. This can be considered occasional rainfall intensity for events with low occurrence in the Saar-Mosel valley (Reiter et al., 2016; Rodrigo Comino, 2015). We assumed the rainfall intensity (kinetic energy and drop size distribution) using the calibration of Iserloh et al. $(2012,2013$ a) to be able to compare results from regions with differing natural rainfall intensities. We measured the rainfall intensity at the beginning and at the end of the test; only when the intensity was constant (a maximum difference of $5 \%$ to $10 \%$ ), the experiment was considered successful. Experiment durations were 30 minutes. All of the rainfall simulations were conducted between 2014 and 2015 on representative plots.

Plot characteristics such as vegetation and stone cover, roughness (using the chain method by Saleh, 1993), slope and previous soil moisture were measured. During the experiment, total runoff and mobilized materials were sampled in PE bottles. The 
30-minutes-experiments were divided into six intervals (five minutes each). At the beginning of every new interval, the bottles were changed. In the laboratory, the bottles were weighed and the total runoff (L) was obtained gravimetrically, subtracting also the sediment amount. The collected water in every bottle was filtered separately with circular fine-meshed filter papers. Every filter was dried at $105{ }^{\circ} \mathrm{C}$ and weighed for obtaining total soil material for each interval.

A total of 22 rainfall simulations were conducted between October (2014) and April (2015), 11 in the conventional vineyard and 11 in the organic one.

Several differences of plot characteristics of both study sites can be noted (Table 1). Although the slope is fairly similar with $17.6 \pm 5.1^{\circ}$ in the conventional vineyard and $16.9 \pm 4.9^{\circ}$ in the organic one, vegetation cover in the organic vineyard reaches up to $78.6 \pm 14.8 \%$, but only $36.8 \pm 32.2 \%$ in the conventional one. The latter shows a stone cover of $34.3 \pm 25.2 \%$, while the former displays lower values of $22.3 \pm 15.1 \%$. Plot roughness values were basically the same for both study sites $(\approx 1)$. At the beginning of the simulation, antecedent soil moisture values were higher in the conventional $(13.9 \pm 1.6 \%)$ than in the organic vineyard $(11.8 \pm 5.8 \%)$.

Table 1. Environmental characteristics of the studied areas.

\begin{tabular}{cccccccc} 
& Clay & Silt & Sand & Slope $\left({ }^{\circ}\right)$ & $\begin{array}{c}\text { Vegetation } \\
\text { cover }(\%)\end{array}$ & $\begin{array}{c}\text { Stone } \\
\text { cover }(\%)\end{array}$ & $\begin{array}{c}\text { Soil moisture } \\
(\%)\end{array}$ \\
\hline Conventional & 10.6 & 40.4 & 49 & $17.6 \pm 5.12$ & $36.8 \pm 32.2$ & $34.3 \pm 25.2$ & $13.9 \pm 1.6$ \\
\hline Organic & 8.1 & 31 & 60.9 & $16.9 \pm 4.9$ & $78.6 \pm 14.8$ & $22.3 \pm 15.1$ & $11.8 \pm 5.8$ \\
\hline
\end{tabular}

\subsubsection{Gerlach troughs}

The Gerlach trough design was developed by Rüttimann and Prasuhn (1993) following the approach of Gerlach (1967), and tested previously for soil erosion measurements on maize crops (Rüttimann et al., 1995) and German conventional vineyards (Rodrigo Comino et al., 2015; 2016b). Four sediment collectors with a width of $150 \mathrm{~cm}$ (Fig. 2) were situated in the inter-rows and part of the rows (about 1 meter width) on the backslopes in both tested areas. Amounts of sediment (g), overland flow (L) and sediment concentration $\left(\mathrm{g} \mathrm{L}^{-1}\right)$ were calculated proportionally in $\mathrm{g} \mathrm{m}^{-1}, \mathrm{~L} \mathrm{~m}^{-1}$ and $\mathrm{g} \mathrm{L}^{-1}$, respectively (Gerlach, 1967). The open soil erosion plots give information about the soil and water losses but the contributing area is uncertain, which is why the soil erosion rates or overland flow are shown in $\mathrm{g} \mathrm{m}^{-1}$ and $\mathrm{L} \mathrm{m}^{-1}$, respectively. Additionally, all of them are connected to collecting tanks (100-200 L) to be prepared for extreme rainfallrunoff events that exceed the storage capacity of each Gerlach trough (upwards from 30 L). Close to the sediment collectors in both vineyards, an agro-climate station (http:// www.wetter.rlp.de) delivered the rainfall amount and intensity after each event. The upslope length in the vineyards was approximately 60-80 m. The main limit of this tool is the impossibility to collect the water inflow from sub-surface flow. The maintenance of the equipment, emptying sediments and overland flow, was performed every one to 
four weeks, depending on the rainfall events. All collected samples were transported to the laboratory for drying, weighing and quantifying sediments and overland flow. The soil erosion monitoring was carried out between 22.04.2015 and 17.08.2016, containing a total of 33 natural rainfall events. When the rainfall did not activate the overland flow but soil loss occurred, anthropogenic factors (trampling of workers, machinery, removal and re-placement of troughs) were the main cause to initiate the soil erosion events.
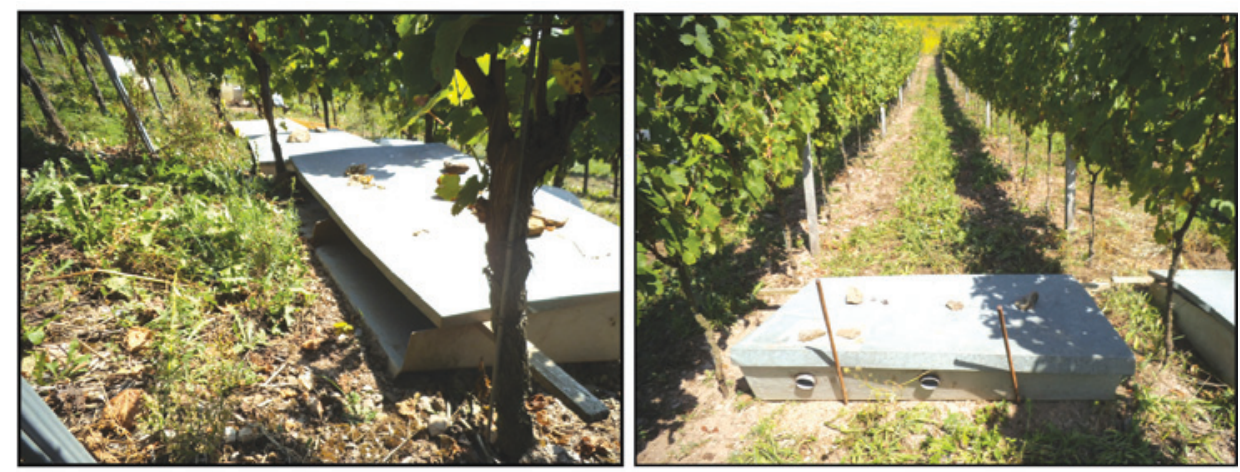

Figure 2. Gerlach troughs in the studied plots. A: conventional vineyard; B: organic farming.

\subsubsection{Statistical analysis}

Rainfall simulation results were represented in form of box plots, showing the medians (continued line), the averages (discontinued line) and outliers.

Soil erosion results from the open plots were organized following events with little to moderate precipitation $(<20 \mathrm{~mm})$ and high erosion results $\left(>5 \mathrm{~g} \mathrm{~m}^{-1}\right)$, and events with larger amounts of rainfall $(>20 \mathrm{~mm})$ that led to a lower soil losses $\left(<5 \mathrm{~g} \mathrm{~m}^{-1}\right)$. Moreover, to compare the variability of the results the relative difference in the replicated erosion plots proposed by Nearing et al. (1999) was used.

$$
E q \cdot 1 R_{\text {diff }} \frac{M 2-M 1}{M 2+M 1}
$$

M1 and M2 are the paired values of soil loss and overland flow from two replicate plots. The values can vary between -1 and +1 . When $M 2=M 1$, the relative differences among them are avoided. The second comparison of the soil loss and overland flow results from the paired-Gerlach troughs was performed using a Mann-Whitney Rank Sum Test with the SigmaPlot 13 (Systat Software, Inc).

\section{Results}

\subsection{Rainfall simulation results}

The results of the 22 rainfall simulations are presented by showing the total averages, maximum and minimum values (Fig. 3) and per interval (Fig. 4) in box plots. 
The conventional vineyard showed a total average suspended sediment load (SSL) of $33.75 \mathrm{~g} \mathrm{~m}^{-2}$ with maximum values about $96.8 \mathrm{~g} \mathrm{~m}^{-2}$, while the mean runoff $(\mathrm{R})$ was $5.25 \mathrm{~L} \mathrm{~m}^{-2}$. The maximum runoff observed was $17.03 \mathrm{~L} \mathrm{~m}^{-2}$. The average suspended sediment concentration (SSC) was therefore $4.26 \mathrm{~g} \mathrm{~L}^{-1}$ (maximum values reached up to $10.93 \mathrm{~g} \mathrm{~L}^{-1}$ ), with a mean runoff coefficient (RC) about $23.33 \%$ and an average infiltration coefficient (IC) of $76.67 \%$. The maximum runoff coefficient was $60.5 \%$, while the minimum infiltration coefficient was $39.5 \%$. During the experiment (Fig. 4), the average interval values showed the runoff starting during the first interval on the conventional vineyard and rising to the sixth interval reaching its maximum. Erosion was also present from the first interval, decreasing in the second to rise again until the fifth interval and still showing high values in the sixth. The highest runoff coefficient and the lowest infiltration coefficient were also found in the sixth interval, while the highest sediment concentration was present in the fourth interval.
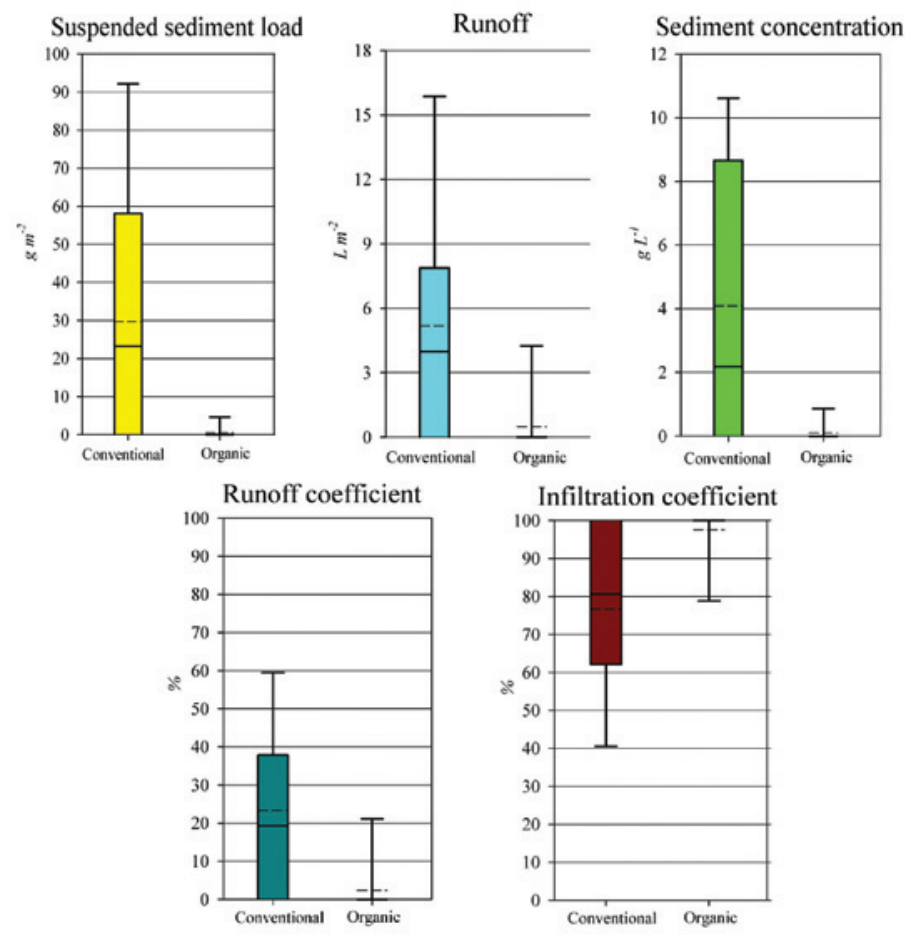

Figure 3. Total average of suspended sediment load, runoff, sediment concentration, runoff and infiltration coefficients (5th/95th percentiles; short dash: mean line; solid line: median).

In the organic vineyard only one of 11 simulations produced runoff and erosion (Fig. 3). The 10 remaining simulations showed infiltration coefficients of $100 \%$ and therefore no suspended sediment load. The unique simulation that showed soil erosion obtained a total runoff of $5.32 \mathrm{~L} \mathrm{~m}^{-2}$ and suspended sediment load about $5.75 \mathrm{~g} \mathrm{~m}^{-2}$. The 
total suspended sediment concentration was $1.08 \mathrm{~g} \mathrm{~L}^{-1}$, with a total runoff coefficient of $26.40 \%$ and a corresponding infiltration coefficient of $73.6 \%$. During the simulation (Fig. 4), the maximum suspended sediment load and runoff were $2.89 \mathrm{~g} \mathrm{~m}^{-2}$ and $2.84 \mathrm{~L} \mathrm{~m}^{-2}$, respectively. Runoff began in the fourth interval, rising up to the sixth interval where it reached its maximum. Sediment yield reached its maximum in the fifth interval and declined slightly in the sixth. Thus, the value for the runoff coefficient was the highest in the sixth interval, while the highest sediment concentration was found in the fifth interval. The average for all 11 simulations was therefore: $\mathrm{R}=0.08 \mathrm{~L} \mathrm{~m}^{-2}$, $\mathrm{SSL}=0.09 \mathrm{~g} \mathrm{~m}^{-2}, \mathrm{SSC}=0.05 \mathrm{~g} \mathrm{~L}^{-1}, \mathrm{RC}=2.40 \%$ and $\mathrm{IC}=97.60 \%$.
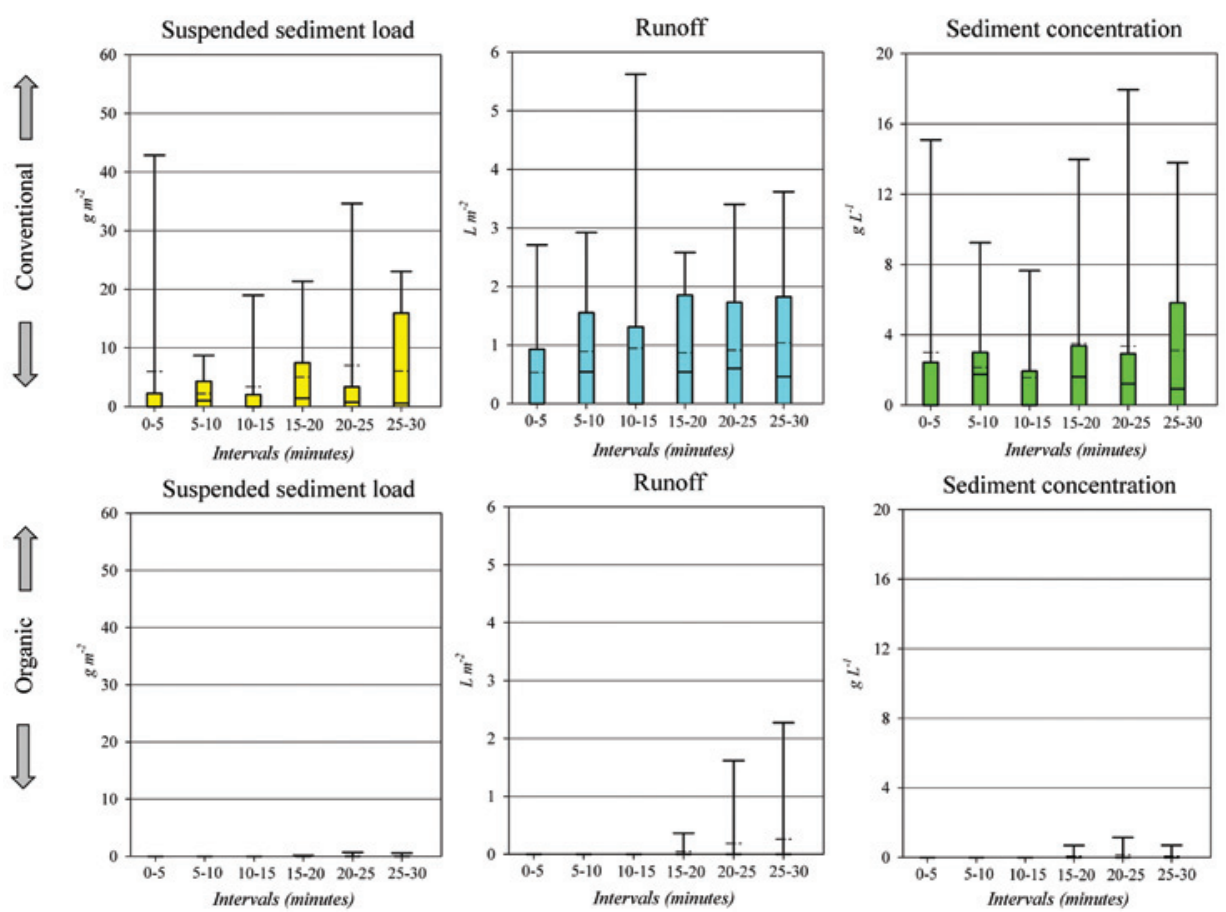

Figure 4. Total means per intervals of suspended sediment load, runoff and sediment concentration (5th/95th percentiles; short dash: mean line; solid line: median).

\subsection{Monitoring of overland flow, soil loss and sediment concentration}

The recorded rainfall events as well as mean and maximum rainfall intensities are shown in Table 2. The highest rainfall was measured to be $106 \mathrm{~mm}$ by 14.06 .2016 , while the minimum added up to $4.4 \mathrm{~mm}$ by 14.07.2015. During the months AprilSeptember 5 out of 7 rainfall events with a total rainfall of more than $40 \mathrm{~mm}$ were quantified. The events with the highest maximum rainfall intensities also occurred in summertime, while events with lower maximum rainfall intensities occurred mostly 
in winter. The highest maximum rainfall intensity as well as the maximum mean rainfall intensity was measured on 22.07 .2016 with $30.8 \mathrm{~mm} \mathrm{~h}^{-1}$ and $1.93 \mathrm{~mm} \mathrm{~h}^{-1}$, respectively.

Table 2. Climate conditions during the monitoring period.

\begin{tabular}{cccccccccc}
\hline ID & Date & Total & $\dot{x}$ & Max. & ID & Date & Total & $x$ & Max. \\
\hline 1 & 22.04 .2015 & 14.6 & 0.2 & 1.2 & 18 & 14.12 .2015 & 9.6 & 0.26 & 1.8 \\
\hline 2 & 28.04 .2015 & 24 & 0.46 & 4.8 & 19 & 26.01 .2016 & 49.2 & 0.27 & 3 \\
\hline 3 & 12.05 .2015 & 12.6 & 0.3 & 1.2 & 20 & 03.02 .2016 & 20.2 & 0.4 & 2.6 \\
\hline 4 & 19.05 .2015 & 7.4 & 0.6 & 0.6 & 21 & 11.02 .2016 & 25.8 & 0.5 & 3.6 \\
\hline 5 & 02.06 .2015 & 14.2 & 0.55 & 3.6 & 22 & 25.02 .2016 & 33.4 & 0.35 & 3.2 \\
\hline 6 & 16.06 .2015 & 16 & 4 & 11.6 & 23 & 05.04 .2016 & 70.2 & 0.34 & 3.6 \\
\hline 7 & 30.06 .2015 & 32.4 & 1.4 & 4 & 24 & 21.04 .2016 & 18 & 0.43 & 2.8 \\
\hline 8 & 14.07 .2015 & 4.4 & 0.65 & 2.2 & 25 & 03.05 .2016 & 37.5 & 0.33 & 1.7 \\
\hline 9 & 21.07 .2015 & 15.2 & 1.06 & 9.8 & 26 & 18.05 .2016 & 11.1 & 0.31 & 1.7 \\
\hline 10 & 29.07 .2015 & 16.2 & 0.63 & 5.8 & 27 & 31.05 .2016 & 71.5 & 0.63 & 10.3 \\
\hline 11 & 05.08 .2015 & 8 & 0.5 & 3 & 28 & 14.06 .2016 & 106 & 1.6 & 15.8 \\
\hline 12 & 26.08 .2015 & 22 & 0.6 & 2.8 & 29 & 23.06 .2016 & 26.2 & 1.01 & 7.7 \\
\hline 13 & 03.09 .2015 & 46 & 1.6 & 7.8 & 30 & 28.06 .2016 & 18.2 & 1.16 & 3.6 \\
\hline 14 & 20.10 .2015 & 94.4 & 0.38 & 4.2 & 31 & 22.07 .2016 & 75 & 1.93 & 30.8 \\
\hline 15 & 10.11 .2015 & 6.2 & 0.2 & 0.6 & 32 & 11.08 .2016 & 19 & 0.25 & 2.6 \\
\hline 16 & 20.11 .2015 & 38.8 & 0.45 & 4.4 & 33 & 17.08 .2016 & 0.1 & 0.1 & 0.1 \\
\hline 17 & 01.12 .2015 & 16 & 0.3 & 2.4 & & & & & \\
\hline
\end{tabular}

* Total: total rainfall $(\mathrm{mm}) ; \dot{x}:$ mean rainfall intensity $\left(\mathrm{mm} \mathrm{h}^{-1}\right)$;

Max.: maximum rainfall intensity $\left(\mathrm{mm} \mathrm{h}^{-1}\right)$.

Out of 33 recorded rainfall events (Table 3), 21 lead to runoff in Gerlach trough 1 as well as 14 in trough 2 (both conventional vineyard), while 11 produced runoff collected in troughs 3 and 4 (both organic vineyard). The total runoff observed was $172.58 \mathrm{~L} \mathrm{~m}^{-1}$ (Gerlach trough 1) and $105.52 \mathrm{~L} \mathrm{~m}^{-1}$ (Gerlach trough 2) in the conventional vineyard. The values collected in the organic vineyard (Gerlach troughs 3 and 4) were $21.65 \mathrm{~L} \mathrm{~m}^{-1}$ and $12.69 \mathrm{~L} \mathrm{~m}^{-1}$. The maximum value for overland flow was $52.44 \mathrm{~L} \mathrm{~m}^{-1}$ on the conventional vineyard, whereas the maximum on the organic was $10.31 \mathrm{Lm}^{-1}$ during the same event. In Table 4, the relative difference proposed by Nearing et al. (1999) showed that there was a high variability in the tow-paired sampling sediment collectors in the conventional vineyard $\left(\mathrm{R}_{\text {diff }}=-0.32\right)$, which were confirmed with the Mann-Whitney 
Rank Sum Test with a statistically significant difference in the median values of the two troughs $(\mathrm{P}=0.05)$, meaning the difference was great enough to exclude the possibility that the difference was due to random sampling variability. On the other hand, there was no statistically significant difference for the Gerlach troughs on the organic vineyards $\left(\mathrm{P}=0.976, \mathrm{R}_{\mathrm{diff}}=0.0051\right)$.

Table 3. Total soil loss, overland flow and sediment concentration results in conventional and organic vineyards.

\begin{tabular}{lcccc}
\hline \multicolumn{1}{c}{ Soil management } & \multicolumn{2}{c}{ Conventional } & \multicolumn{2}{c}{ Organic } \\
\hline Gerlach trough & 1 & 2 & 1 & 2 \\
\hline Overland flow $\left(\mathrm{L} \mathrm{m}^{-1}\right)$ & 172.58 & 105.52 & 21.65 & 12.69 \\
\hline Soil loss $\left(\mathrm{g} \mathrm{m}^{-1}\right)$ & 6503.77 & 3314.63 & 258.89 & 143.16 \\
\hline Sediment concentration $\left(\mathrm{g} \mathrm{L}^{-1}\right)$ & 37.69 & 31.41 & 11.96 & 11.28 \\
\hline Total rainfall $(\mathrm{mm})$ & \multicolumn{3}{c}{979.4} \\
\hline
\end{tabular}

Table 4. Relative differences in two-paired erosion plots.

\begin{tabular}{lcccc}
\hline \multicolumn{1}{c}{ Soil management } & \multicolumn{2}{c}{ Conventional } & \multicolumn{2}{c}{ Organic } \\
\hline Soil erosion parameters & Overland flow & Soil loss & Overland flow & Soil loss \\
\hline $\mathrm{R}_{\text {diff }}$ (Nearing et al., 1999) & -0.32 & -0.37 & 0.0051 & -0.055 \\
\hline Mann-Whitney Rank Sum Test & $\mathrm{P}=0.05$ & $\mathrm{P}=0.05$ & $\mathrm{P}=0.976$ & $\mathrm{P}=0.783$ \\
\hline
\end{tabular}

The total soil loss on the conventional vineyard added up to $6503.77 \mathrm{~g} \mathrm{~m}^{-1}$ (Gerlach trough 1) and $3314.63 \mathrm{~g} \mathrm{~m}^{-1}$ (Gerlach trough 2). The total soil losses in the organic vineyards reached up to $258.89 \mathrm{~g} \mathrm{~m}^{-1}$ for Gerlach trough 3 and up to $143.16 \mathrm{~g} \mathrm{~m}^{-1}$ for the other paired-one (4). Maxima amounted to $2500 \mathrm{~g} \mathrm{~m}^{-1}$ in the sediment collector 2 (75.4\% of the total soil loss in one event) in the conventional vineyard and up to $125.09 \mathrm{~g} \mathrm{~m}^{-1}$ in the Gerlach trough number $4(87.4 \%$ of the total soil loss in one event) in the organic vineyard. As with the overland flow, the soil loss values in the conventional vineyard also showed statistically significant differences between the soil erosion rates $\left(P=0.05, R_{\text {diff }}=-0.37\right)$. The $R_{\text {diff }^{-}}$-value (Nearing et al., 1999) in the organic vineyard amounted to -0.055 , while the Mann-Whitney Rank Sum Test obtained a P-value of 0.783 , both showing no difference in data and the median (almost any variability), respectively.

It becomes apparent in Figures 5 and 6 that the soil losses had no clear relationship with rainfall amounts and intensities. When focusing on events from little to moderate total precipitation $(<20 \mathrm{~mm})$ and high erosion rates $\left(>5 \mathrm{~g} \mathrm{~m}^{-1}\right)$ the events $6,9,11,24,30$ and 32 are singled out (Table 5). All of these events coincided with soil tillage practices, like ploughing, pruning and harvesting, although events 6 and 9 showed a high maximum rainfall intensity (Table 2). Events 24 and 32 induced high erosion in 3 out of 4 Gerlach troughs. These events occurred on 21.04.2016 and 11.08.2016, respectively. Gerlach 
trough 1 collected eroded sediment during the events 11 and 30, which did not show high maximum rainfall intensities although they occurred during the summer months (5.08.2015 and 28.06.2016, respectively) when soil is frequently tilled. Although not shown in Table 5, event 2 activated erosion but no runoff, which could be an indicator for tillage erosion. Table 5 also shows events with precipitation $>20 \mathrm{~mm}$ that led to a soil loss of $<5 \mathrm{~mm}$. The number of events to fit this restriction amounts to $6-9$ in the conventional and $12-14$ in the organic vineyard.

Table 5. Characterization of natural rainfall events in the studied conventional and organic vineyards.

\begin{tabular}{|c|c|c|c|c|c|}
\hline \multirow[b]{2}{*}{$\begin{array}{l}\text { Type of } \\
\text { events }\end{array}$} & \multirow[b]{2}{*}{ Rainfall/erosion } & \multicolumn{2}{|c|}{ Conventional } & \multicolumn{2}{|c|}{ Organic } \\
\hline & & $\begin{array}{l}\text { Gerlach } \\
\text { trough } 1\end{array}$ & $\begin{array}{l}\text { Gerlach } \\
\text { trough } 2\end{array}$ & $\begin{array}{l}\text { Gerlach } \\
\text { trough } 3\end{array}$ & $\begin{array}{l}\text { Gerlach } \\
\text { trough } 4\end{array}$ \\
\hline \multirow{2}{*}{$\begin{array}{l}<20 \mathrm{~mm}^{-} \\
>5 \mathrm{~g} \mathrm{~m}^{-1}\end{array}$} & Number of event & $\begin{array}{c}6,9,11, \\
24,30,32\end{array}$ & $9,24,30,32$ & 24,32 & \\
\hline & $\begin{array}{c}\text { Total } \\
\left(\mathrm{mm} / \mathrm{g} \mathrm{m}^{-1}\right)\end{array}$ & $\begin{array}{l}94.4 / \\
929.3 \\
\end{array}$ & $\begin{array}{l}70.4 / \\
2667.1\end{array}$ & $37.0 / 98.6$ & $-/-$ \\
\hline \multirow[t]{2}{*}{$\begin{array}{l}>20 \mathrm{~mm} \\
<5 \mathrm{~g} \mathrm{~m}^{-1}\end{array}$} & Number of event & $\begin{array}{l}12,16,20 \\
22,23,25\end{array}$ & $\begin{array}{l}7,12,14, \\
16,19,20, \\
22,23,25\end{array}$ & $\begin{array}{c}2,7,13,14, \\
16,20,22, \\
23,25,27, \\
29,31\end{array}$ & $\begin{array}{c}7,12,13,14 \\
16,20,21 \\
22,23,25, \\
27,28,29,31\end{array}$ \\
\hline & $\begin{array}{c}\text { Total } \\
\left(\mathrm{mm} / \mathrm{g} \mathrm{m}^{-1}\right)\end{array}$ & $222.1 / 5.7$ & $398.1 / 6.3$ & $569.6 / 8.4$ & 699.4 / 9.3 \\
\hline
\end{tabular}

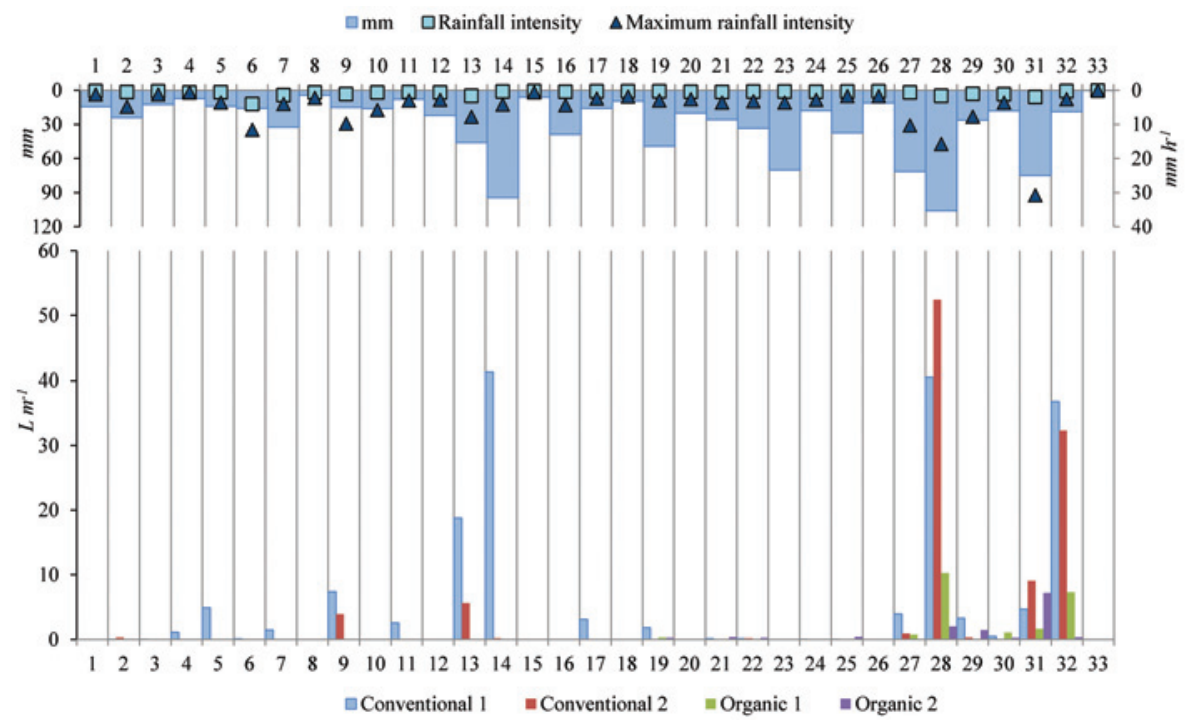

Figure 5. Total rainfall events and overland flow in organic and conventional vineyards. 


\section{Discussion}

A comparison of runoff and soil loss in conventional and organic vineyards was carried out using a portable rainfall simulator as well as Gerlach field troughs. Although the two methods (simulations vs. open plots) cannot be compared directly, both showed great differences between the management types.

Despite that rainfall intensity was higher during the rainfall simulations than during natural events, soil losses and runoff coefficients were higher during the natural events due to the relatively low kinetic energy of the simulated rainfall and the inexact reproduction of the natural rainfall structure by rainfall simulations (Cerdà, 1997; Iserloh et al., 2012; Iserloh et al., 2013b; Lassu et al., 2015). Comparison of both measurement methods is difficult since there is no data about the contributing area during natural events, although it is probably larger than the plots of the rainfall simulations (Chaplot and Le Bissonnais, 2000; Kinnell, 2016) and highly variable between different events and even within an event. In addition, on the open plots, human impact during vineyard management had a high influence on sediment transport (trampling effect, use of machinery, etc.). The complexity of the processes generating transport of sediments is also higher on these plots, since concentrated flow can have a big influence on the measured soil losses in the Gerlach troughs.

Little to no runoff and soil loss were measured in the organic vineyard with grasscover between the lines of wine. Soil sealing has been identified to be one of the main responsible for runoff generation on agricultural land (Peter and Ries, 2013; Hänsel et al., 2016), which did not happen in the studied organic vineyards and thus explains the absence of runoff in 10 of 11 experiments. This could also show effects on grape production, quality of wine and carbon capture and storage (García-Díaz et al., 2017; Marín et al., 2016; Novara et al., 2015). In contrast, the conventionally managed vineyard produced considerably higher values for runoff and soil loss.

Suspended sediment load has been measured in other viticulture areas with different soil management strategies. In Spain, Prosdocimi et al. (2016b) measured on bare and straw-mulch covered soils SSC of $9.8 \mathrm{~g} \mathrm{~L}^{-1}$ and $3.0 \mathrm{~g} \mathrm{~L}^{-1}$, respectively. These values are considerably higher than those measured in the Saar-Mosel Valley, with $2.07 \mathrm{~g} \mathrm{~L}^{-1}$ in the conventional and $0.00 \mathrm{~g} \mathrm{~L}^{-1}$ in the organic vineyard. In comparison to other orchards in the western Mediterranean, these values are also remarkably low: mean SSC values from $1.0 \mathrm{~g} \mathrm{~L}^{-1}$ (straw-covered soil) to $10.9 \mathrm{~g} \mathrm{~L}^{-1}$ (bare soil) were obtained by rainfall simulations in persimmon plantations (Cerdà et al., 2016) in Spain, and from $1.5 \mathrm{~g} \mathrm{~L}^{-1}$ (vegetation cover) and $4.55 \mathrm{~g} \mathrm{~L}^{-1}$ (herbicide use) to $13.65 \mathrm{~g} \mathrm{~L}^{-1}$ (tilled soils) in apricot orchards (Keesstra et al., 2016b). Hence, the average SSC in the conventional vineyard ( $\left.2.77 \mathrm{~g} \mathrm{~L}^{-1}\right)$ of the present study was lower than the SSC measured under uncovered crops but higher than the values obtained under protective covers.

The results can also be compared to those found in vineyards in other areas: in Spain, median values of SSC reached approximately $6 \mathrm{~g} \mathrm{~L}^{-1}$ in Málaga and Valencia (Rodrigo Comino et al., 2016a). In the Ruwer Valley (Germany), close to the vineyards presented here, on steep conventionally managed vineyards of different ages, average 
SSC were for 4 years old vines $7 \mathrm{~g} \mathrm{~L}^{-1}$ and for 35-40 years old vines $6.2 \mathrm{~g} \mathrm{~L}^{-1}$. In these steep vineyards under conventional management in Spain and Germany, sediment concentrations are similar because the areas are characterized by shallow and unprotected bare soils. The vineyard with organic management showed sediment concentrations close to zero, much lower than all the conventionally managed vineyards of different ages in the region, located on the same geological substrate (Rodrigo Comino et al., 2015, 2016a), suggesting that the determining factor for soil erosion control is the management type.

In a study carried out in Spanish vineyards, SSC generated by natural rainfall events and collected in Gerlach-troughs ranged from 0.2 to $27 \mathrm{~g} \mathrm{~L}^{-1}$, depending on the disturbance of the soil (Ramos and Martínez-Casasnovas, 2007). On the steep slopes of the Saar vineyards, the highest sediment concentrations reached up to $6792 \mathrm{~g} \mathrm{~L}^{-1}$. These samples were characterised by large amounts of coarse material and soil, and were collected without or with very low rainfall and runoff amounts, suggesting soil and sediment translocation by trampling and tillage activities. Excluding these extreme values, SSC ranged from $0.1 \mathrm{~g} \mathrm{~L}^{-1}$ to $127 \mathrm{~g} \mathrm{~L}^{-1}$, showing higher values than the ones obtained in Spain.

Albeit similar conditions regarding slope gradient and soil type, runoff and soil loss measured with rainfall simulations were also higher in the conventional vineyard than in the organic one. On the other hand, the conventionally managed vineyard soils showed a higher content of soil organic matter. This suggests that differences in runoff and erosion intensities cannot be explained by single soil parameters, but by the development or degradations status of the soil (see also Seeger, 2007). Although the surface cover varies between the two management types, it might not be the only reason for the difference in the initial soil erosion processes. The age of the vineyard is also a key factor controlling soil erosion intensity. Rodrigo Comino et al. (2015; 2016e) observed via botanic benchmarks on recently planted vineyards (approx. 4 yr) a decrease of soil erosion rates from $62.5 \mathrm{Mg} \mathrm{ha}^{-1} \mathrm{yr}^{-1}$ to $33.5 \mathrm{Mg} \mathrm{ha}^{-1} \mathrm{yr}^{-1}$ in two years, whilst the erosion rates on old vineyards $(>30 \mathrm{yr}$ ) were one order of magnitude lower (decreasing in the same period from 3.4 Mg ha $\mathrm{Mr}^{-1}$ to $3.3 \mathrm{Mg} \mathrm{ha}^{-1} \mathrm{yr}^{-1}$ ). This shows that the plantation of vineyards leads to the highest soil erosion rates, which decrease substantially with time.

The plantation scheme on the steep sloping vineyards in the Mosel area has been designed for the use of machinery for soil and plant management. Its impact on soils, e.g. compaction, has been observed by different authors (Rodrigo Comino et al., 2016a; 2016c; Cerdà et al., 2016). Lieskovský and Kenderessy (2014) compared different soil managements such as hoeing by hand and using machinery, and confirmed that the first one was protective for the soils, whereas the second considerably enhanced soil erosion. Despite the use of machinery in the organic management of our test sites, hoeing by hand is still an important management practice and could therefore also explain also the lower erosion rates.

In this study, some soil erosion events were produced by trampling. Soil translocation by trampling has also been observed during harvest and under other crops in Spain and Germany (Rodrigo Comino et al., 2015; 2016b). Effects of human 
trampling on soils and soil erosion were also reported under dense vegetation (Quinn et al., 1980), as well as effects on soil compaction of forest soils under heavy use (Godefroid and Koedam, 2004). As a large part of the management of the organic vineyard is done without machinery and with high frequency, this may be an important contribution to soil erosion. The event 2 (Fig. 6), which activated erosion but no runoff in Gerlach trough 4, occurred during the harvest period, where the vine growers pass several times for selecting the best mature grapes.

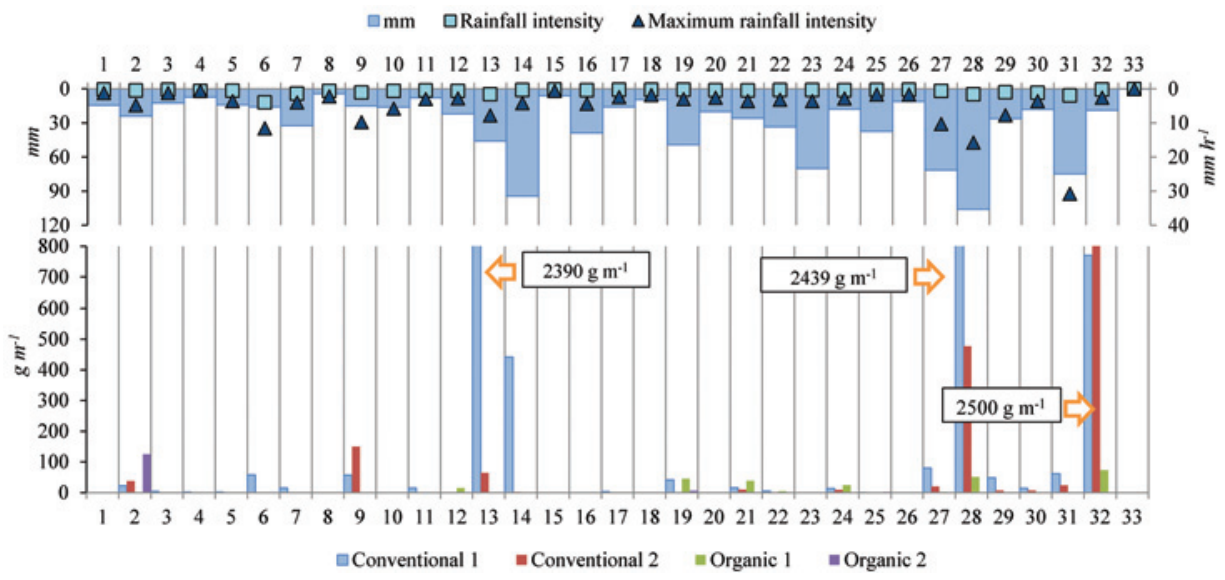

Figure 6. Total rainfall events and soil loss in organic and conventional vineyards.

There was a high variability between the values of the two Gerlach troughs installed in the conventional vineyard, as shown by the $\mathrm{R}_{\text {diff }}$-values (Nearing et al., 1999) and the Mann-Whitney Rank Sum Test (Table 4). There was no statistical indication that the same variability existed in the organic vineyards. Since the Gerlach troughs in this study encompassed the total width between the individual rows, they also collected runoff and erosion from compacted wheel tracks in both the organic and conventional vineyard. The soils of the organic vineyard were possibly less compacted than those on the conventional one and also showed a dense vegetation cover, thus stopping runoff nearly completely. Nearing et al. (1999) also noted that when erosion values are low, more plots are needed to obtain a certain level of similarity. The results shown in this study do not agree with Nearing's conclusion, since there is no statistical variability in the results of the organic vineyard, where values are low, but rather in the high soil loss-yielding conventional vineyard. There are however uncertainties about how long the monitoring period and how big the plot should be to obtain reliable data. The statistical methods used here lead to the conclusion that soil loss in conventionally managed vineyards shows a higher spatial variability than in organic vineyards. But further monitoring is needed, if possible with a higher temporal resolution, to confirm this variability. Soil loss in organically managed vineyards clearly related to the density of the vegetation cover amongst other factors (Morvan et al., 2014). 
Since erosion in vineyards is a wide-spread problem (Rodrigo Comino et al., 2016d; Prosdocimi et al., 2016a; Biddoccu et al., 2016), different management strategies are applied to reduce it. Grass cover or cover crops are often used to reduce runoff and erosion (Biddoccu et al., 2016, Ruiz-Colmenero et al., 2011, 2013, Novara et al., 2011) but in some other cases they can enhance the variability of runoff and soil loss since the grass cover is not dense enough to halt runoff in the wheel tracks (Morvan et al., 2014; Sastre et al., 2016). Blavet et al. (2009) found that especially two factors were controlling runoff generation and erosion: soil cover (by vegetation, mulch or pruning residues) and the topsoil aggregate stability. Both hinder the formation of impermeable crusts.

\section{Conclusion}

For this study 22 rainfall simulations were carried out in conventionally and organically managed vineyards. Monitoring results were acquired using 4 Gerlach troughs. The conventional vineyard showed higher soil loss during the rainfall simulations than the organic one, which was unresponsive in terms of runoff and soil loss during 10 out of 11 rainfall simulations. Erosion could be activated by soil tillage and without precipitation or runoff. This was measured by the Gerlach troughs placed in the field.

Finally, the conventional vineyard showed a high variability concerning runoff and soil loss between the two Gerlach troughs placed in two adjoining rows in the field. The organic vineyard showed no such variability, though the measured soil erosion was very much lower than the one measured in the conventionally managed vineyard.

This information could be a good reference point for future land management planning and can help the wine growers with their decisions.

\section{Acknowledgements}

We acknowledge the winery "Weingut Dr. Frey" (Kanzem) for providing access to the study areas. Moreover, we acknowledge the geomorphology and soil laboratory technicians María Pedraza and Rubén Rojas of GSoilLab (Málaga University) for the soil analysis. We also thank the Ministerio de Educación, Cultura y Deporte de España (Spanish Ministry of Education, Culture and Sport, Spain) for the Scholarship grant (FPU) awarded to J. Rodrigo-Comino.

\section{References}

Arnáez, J., Lasanta, T., Ruiz-Flaño, P., Ortigosa, L. 2007. Factors affecting runoff and erosion under simulated rainfall in Mediterranean vineyards. Soil and Tillage Research 93, 324-334. http://doi.org/10.1016/j.still.2006.05.013.

Ashenfelter, O., Storchmann, K. 2010a. Measuring the economic effect of global warming on viticulture using auction, retail, and wholesale prices. Review of Industrial Organization 37, 51-64. http://doi.org/10.1007/s11151-010-9256-6.

Ashenfelter, O., Storchmann, K. 2010b. Using hedonic models of solar radiation and weather to assess the economic effect of climate change: The case of Mosel Valley vineyards. Review of Economics and Statistics 92, 333-349. http://doi.org/10.1162/rest.2010.11377. 
Biddoccu, M., Ferraris, S., Opsi, F., Cavallo, E. 2016. Long-term monitoring of soil management effects on runoff and soil erosion in sloping vineyards in Alto Monferrato (North-West Italy). Soil and Tillage Research 155, 176-189. http://doi.org/10.1016/j.still.2015.07.005.

Blavet, D., De Noni, G., Le Bissonnais, Y., Leonard, M., Maillo, L., Laurent, J.Y., Asseline, J., Leprun, J.C., Arshad, M.A., Roose, E. 2009. Effect of land use and management on the early stages of soil water erosion in French Mediterranean vineyards. Soil and Tillage Research 106, 124-136. http://doi.org/10.1016/j.still.2009.04.010.

Blum, W.E.H. 2005. Functions of Soil for Society and the Environment. Reviews in Environmental Science and Biotechnology 4, 75-79. http://doi.org/10.1007/s11157-005-2236-x.

Brevik, E.C., Cerdà, A., Mataix-Solera, J., Pereg, L., Quinton, J.N., Six, J., Van Oost, K. 2015. The interdisciplinary nature of soil. SOIL 1, 117-129. http://doi.org/10.5194/soil-1-117-2015.

Bruggisser, O.T., Schmidt-Entling, M.H., Bacher, S. 2010. Effects of vineyard management on biodiversity at three trophic levels. Biological Conservation 143, 1521-1528. http://doi. org/10.1016/j.biocon.2010.03.034.

Bryan, R.B. 2000. Soil erodibility and processes of water erosion on hillslope. Geomorphology 32, 385-415. http://doi.org/10.1016/S0169-555X(99)00105-1.

Cerdà, A. 1997. Soil erosion after land abandonment in a semiarid environment of southeastern Spain. Arid Soil Research and Rehabilitation 11, 163-176. http://doi. org/10.1080/15324989709381469.

Cerdà, A. 1999. Parent material and vegetation affect soil erosion in eastern Spain. Soil Science Society of America Journal 63 (2), 362-368. http://doi.org/10.2136/sssaj1999.03615995006 $300020014 \mathrm{x}$.

Cerdà, A., González-Pelayo, Ó., Giménez-Morera, A., Jordán, A., Pereira, P., Novara, A., Brevik, E.C., Prosdocimi, M., Mahmoodabadi, M., Keesstra, S., Orenes, F.G., Ritsema, C.J. 2016. Use of barley straw residues to avoid high erosion and runoff rates on persimmon plantations in Eastern Spain under low frequency-high magnitude simulated rainfall events. Soil Research 54, 154-165. http://doi.org/10.1071/SR15092.

Cerdan, O., Govers, G., Le Bissonnais, Y., Van Oost, K., Poesen, J., Saby, N., Gobin, A., Vacca, A., Quinton, J., Auerswald, K., Klik, A., Kwaad, F.J.P.M., Raclot, D., Ionita, I., Rejman, J., Rousseva, S., Muxart, T., Roxo, M.J., Dostal, T. 2010. Rates and spatial variations of soil erosion in Europe: A study based on erosion plot data. Geomorphology 122, 167-177. http:// doi.org/10.1016/j.geomorph.2010.06.011.

Chaplot, V., Le Bissonnais, Y. 2000. Field measurements of interrill erosion under different slopes and plot sizes. Earth Surface Processes and Landforms 25, 145-153. http://doi.org/10.1002/ (SICI)1096-9837(200002)25:2<145::AID-ESP51>3.0.CO;2-3.

Chevigny, E., Quiquerez, A., Petit, C., Curmi, P. 2014. Lithology, landscape structure and management practice changes: Key factors patterning vineyard soil erosion at metre-scale spatial resolution. Catena 121, 354-364. http://doi.org/10.1016/j.catena.2014.05.022.

Corbane, C., Jacob, F., Raclot, D., Albergel, J., Andrieux, P. 2012. Multitemporal analysis of hydrological soil surface characteristics using aerial photos: A case study on a Mediterranean vineyard. International Journal of Applied Earth Observations and Geoinformation 18, 356367. http://doi.org/10.1016/j.jag.2012.03.009.

Costantini, E.A.C., Agnelli, A.E., Fabiani, A., Gagnarli, E., Mocali, S., Priori, S., Simoni, S., Valboa, G. 2015. Short-term recovery of soil physical, chemical, micro- and mesobiological functions in a new vineyard under organic farming. SOIL 1, 443-457. http://doi.org/10.5194/ soil-1-443-2015.

Ferrero, A., Usowicz, B., Lipiec, J. 2005. Effects of tractor traffic on spatial variability of soil strength and water content in grass covered and cultivated sloping vineyard. Soil and Tillage Research 84, 127-138. http://doi.org/10.1016/j.still.2004.10.003. 
Galati, A., Gristina, L., Crescimanno, M., Barone, E., Novara, A. 2015. Towards more efficient incentives for agri-environment measures in degraded and eroded vineyards. Land Degradation \& Development 26, 557-564. http://doi.org/10.1002/ldr.2389.

García-Díaz, A., Allas, R.B., Gristina, L., Cerdà, A., Pereira, P., Novara, A. 2016. Carbon input threshold for soil carbon budget optimization in eroding vineyards. Geoderma 271, 144-149. http://doi.org/10.1016/j.geoderma.2016.02.020.

García-Díaz, A., Bienes, R., Sastre, B., Novara, A., Gristina, L., Cerdà, A. 2017. Nitrogen losses in vineyards under different types of soil groundcover. A field runoff simulator approach in central Spain. Agriculture, Ecosystems and Environment 236, 256-267. http://doi. org/10.1016/j.agee.2016.12.013.

Gerlach, T. 1967. Hillslope troughs for measuring sediment movement. Revue de Géomorphologie Dynamique 4, 173-175.

Giménez-Morera, A., Sinoga, J.D.R., Cerdà, A. 2010. The impact of cotton geotextiles on soil and water losses from Mediterranean rainfed agricultural land.Land Degradation \& Development 21, 210-217. http://doi.org/10.1002/ldr.971.

Godefroid, S., Koedam, N. 2004. The impact of forest paths upon adjacent vegetation: effects of the path surfacing material on the species composition and soil compaction. Biological Conservation 119, 405-419. http://doi.org/10.1016/j.biocon.2004.01.003.

Hacisalihoglu, S. 2007. Determination of soil erosion in a steep hill slope with different land-use types: a case study in Mertesdorf (Ruwertal/Germany). Journal of Environmental Biology 28, 433-438.

Hänsel, P., Schindewolf, M., Eltner, A., Kaiser, A., Schmidt, J. 2016. Feasibility of high-resolution soil erosion measurements by means of rainfall simulations and SfM photogrammetry. Hydrology 3, 38. http://doi.org/10.3390/hydrology3040038.

Hueso-González, P., Martínez-Murillo, J.F., Ruiz-Sinoga, J.D. 2016. Effects of topsoil treatments on afforestation in a dry Mediterranean climate (southern Spain). Solid Earth 7, 1479-1489. http://doi.org/10.5194/se-7-1479-2016.

Hueso-González, P., Martínez-Murillo, J.F., Ruiz-Sinoga, J.D. 2017. Beneficios de los acolchados de paja y poda como prácticas para la gestión forestal de montes mediterráneos. Cuadernos de Investigación Geográfica 43 (1), 189-208. http://doi.org/10.18172/cig.3142.

Hueso-González, P., Martínez-Murillo, J.F., Ruiz-Sinoga, J.D. 2014. The Impact of organic amendments on forest soil properties under Mediterranean climatic conditions. Land Degradation \& Development 25, 604-612. http://doi.org/10.1002/ldr.2296.

Iserloh, T., Fister, W., Seeger, M., Willger, H., Ries, J.B. 2012. A small portable rainfall simulator for reproducible experiments on soil erosion. Soil and Tillage Research 124, 131-137. http:// doi.org/10.1016/j.still.2012.05.016.

Iserloh, T., Ries, J.B., Cerdà, A. and Echeverría, M.T., Fister, W., Geißler, C., Kuhn, N.J., León, F.J., Peters, P., Schindewolf, M., Schmidt, J., Scholten, T., Seeger, M. 2013a. Comparative measurements with seven rainfall simulators on uniform bare fallow land. Zeitschrift für Geomorphologie, Suppl. 57, 11-26. http://doi.org/10.1127/0372-8854/2012/S-00085.

Iserloh, T., Ries, J.B., Arnáez, J., Boix-Fayos, C., Butzen, V., Cerdà, A., Echeverría, M.T., Fernández-Gálvez, J., Fister, W., Geißler, C., Gómez, J.A., Gómez-Macpherson, H., Kuhn, N.J., Lázaro, R., León, F.J., Martínez-Mena, M., Martínez-Murillo, J.F., Marzen, M., Mingorance, M.D., Ortigosa, L., Peters, P., Regüés, D., Ruiz-Sinoga, J.D., Scholten, T., Seeger, M., Solé-Benet, A., Wengel, R., Wirtz, S. 2013b. European small portable rainfall simulators: A comparison of rainfall characteristics. Catena 110, 100-112. http://doi. org/10.1016/j.catena.2013.05.013.

IUSS Working Group WRB, 2014. World Reference Base for Soil Resources 2014, World Soil Resources Report. FAO, Rome. 
Keesstra, S.D., Geissen, V., van Schaik, L., Mosse., K., Piiranen, S. 2012. Soil as a filter for groundwater quality. Current Opinions in Environmental Sustainability 4, 507-516. http:// doi.org/10.1016/j.cosust.2012.10.007.

Keesstra, S.D., Bouma, J., Wallinga, J., Tittonell, P., Smith, P., Cerdà, A., Montanarella, L., Quinton, J.N., Pachepsky, Y., van der Putten, W.H., Bardgett, R.D., Moolenaar, S., Mol, G., Jansen, B., Fresco, L.O. 2016a The significance of soils and soil science towards realization of the United Nations Sustainable Development Goals. SOIL 2, 111-128. http:// doi.org/10.5194/soil-2-111-2016.

Keesstra, S., Pereira, P., Novara, A., Brevik, E.C., Azorin-Molina, C., Parras-Alcántara, L., Jordán, A., Cerdà, A. 2016b. Effects of soil management techniques on soil water erosion in apricot orchards. Science of the Total Environment 551-552,357-366. http://doi.org/10.1016/j.scitotenv.2016.01.182.

Kertész, Á., Tóth, A., Szalai, Z., Jakab, G., Kozma, K., Booth, C. A., Fullen, M. A., Davies, K. 2007. Geotextile as a tool against soil erosion in vineyards and orchards. WIT Transactions on Ecology and the Environment 102, 9 pp. http://doi.org/10.2495/SDP070592.

Kinnell, P.I.A. 2016. A review of the design and operation of runoff and soil loss plots. Catena 145, 257-265. http://doi.org/10.1016/j.catena.2016.06.013.

Koch, J., Martin, A., Nash, R. 2013. Overview of perceptions of German wine tourism from the winery perspective. International Journal of Wine Business Research 25, 50-74. http://doi. org/10.1108/17511061311317309.

Kovacs, A.S., Fulop, B., Honti, M. 2012. Detection of hot spots of soil erosion and reservoir siltation in ungauged Mediterranean catchments. Energy Procedia 18, 934-943. http://doi. org/10.1016/j.egypro.2012.05.108.

Lassu, T., Seeger, M., Peters, P., Keesstra, S.D. 2015. The Wageningen rainfall simulator: Set-up and calibration of an indoor nozzle-type rainfall simulator for soil erosion studies. Land Degradation \& Development 26, 604-612. http://doi.org/10.1002/ldr.2360.

Lieskovský, J., Kenderessy, P. 2014. Modelling the effect of vegetation cover and different tillage practices on soil erosion in vineyards: a case study in Vráble (Slovakia) using WATEM/ SEDEM. Land Degradation \& Development 25, 288-296. http://doi.org/10.1002/ldr.2162.

Marín, A., Andrades, M., Iñigo, V., Jiménez-Ballesta, R. 2016. Lead and cadmium in soils of La Rioja vineyards, Spain. Land Degradation \& Development 27, 1286-1294. http://doi. org/10.1002/ldr.2471.

Martínez-Casasnovas, J.A., Ramos, M.C., 2006. The cost of soil erosion in vineyard fields in the Penedès-Anoia Region (NE Spain). Catena 68, 194-199. http://doi.org/10.1016/j. catena.2006.04.007.

Montenegro, A.A.A., Abrantes, J.R.C.B., de Lima, J.L.M.P., Singh, V.P., Santos, T.E.M. 2013. Impact of mulching on soil and water dynamics under intermittent simulated rainfall. Catena 109, 139-149. http://doi.org/10.1016/j.catena.2013.03.018.

Morvan, X., Naisse, C., Malam Issa, O., Desprats, J.F., Combaud, A., Cerdan, O. 2014. Effect of ground-cover type on surface runoff and subsequent soil erosion in Champagne vineyards in France. Soil Use and Management 30, 372-381. http://doi.org/10.1111/sum.12129.

Nearing, M.A., Govers, G., Norton, L.D. 1999. Variability in soil erosion data from replicated plots. Soil Science Society of America Journal 63, 1829-1835. http://doi.org/10.2136/ sssaj1999.6361829x.

Novák, T.J., Incze, J., Spohn, M., Glina, B., Giani, L. 2014. Soil and vegetation transformation in abandoned vineyards of the Tokaj Nagy-Hill, Hungary. Catena 123, 88-98. http://doi. org/10.1016/j.catena.2014.07.017.

Novara, A., Gristina, L., Saladino, S.S., Santoro, A., Cerdà, A. 2011. Soil erosion assessment on tillage and alternative soil managements in a Sicilian vineyard. Soil and Tillage Research 117, 140-147. http://doi.org/10.1016/j.still.2011.09.007. 
Novara, A., Cerdà, A., Dazzi, C., Lo Papa, G., Santoro, A., Gristina, L. 2015. Effectiveness of carbon isotopic signature for estimating soil erosion and deposition rates in Sicilian vineyards. Soil and Tillage Research 152,1-7. http://doi.org/10.1016/j.still.2015.03.010.

Peter, K.D., Ries, J.B. 2013. Infiltration rates affected by land levelling measures in the Souss valley, South Morocco. Zeitschrift für Geomorphologie 57, 59-72. http://doi.org/10.1127/03728854/2012/S-00124.

Probst, B., Schüler, C., Joergensen, R.G. 2008. Vineyard soils under organic and conventional management-microbial biomass and activity indices and their relation to soil chemical properties. Biology and Fertility of Soils 44, 443-450. http://doi.org/10.1007/s00374-0070225-7.

Prosdocimi, M., Burguet, M., Di Prima, S., Sofia, G., Terol, E., Rodrigo Comino, J., Cerdà, A., Tarolli, P. 2016a. Rainfall simulation and Structure-from-Motion photogrammetry for the analysis of soil water erosion in Mediterranean vineyards. Science of the Total Environment 574, 204-215. http://doi.org/10.1016/j.scitotenv.2016.09.036.

Prosdocimi, M., Jordán, A., Tarolli, P., Keesstra, S., Novara, A., Cerdà, A. 2016b. The immediate effectiveness of barley straw mulch in reducing soil erodibility and surface runoff generation in Mediterranean vineyards. Science of the Total Environment 547, 323-330. http://doi. org/10.1016/j.scitotenv.2015.12.076.

Prosdocimi, M., Tarolli, P., Cerdà, A. 2017. Mulching practices for reducing soil water erosion: A review. Earth-Science Reviews. http://doi.org/10.1016/j.earscirev.2016.08.006.

Quinn, N.W., Morgan, R.P.C., Smith, A.J. 1980. Simulation of soil erosion induced by human trampling. Journal of Environmental Management 10, 155-165.

Quiquerez, A., Brenot, J., Garcia, J.-P., Petit, C. 2008. Soil degradation caused by a high-intensity rainfall event: Implications for medium-term soil sustainability in Burgundian vineyards. Catena 73, 89-97. http://doi.org/10.1016/j.catena.2007.09.007.

Quiquerez, A., Chevigny, E., Allemand, P., Curmi, P., Petit, C., Grandjean, P. 2014. Assessing the impact of soil surface characteristics on vineyard erosion from very high spatial resolution aerial images (Côte de Beaune, Burgundy, France). Catena 116, 163-172. http://doi. org/10.1016/j.catena.2013.12.002.

Raclot, D., Le Bissonnais, Y., Louchart, X., Andrieux, P., Moussa, R., Voltz, M. 2009. Soil tillage and scale effects on erosion from fields to catchment in a Mediterranean vineyard area. Agriculture, Ecosystems and Environment 134, 201-210. http://doi.org/10.1016/j. agee.2009.06.019.

Ramos, M.C., Martínez-Casasnovas, J.A. 2006. Impact of land levelling on soil moisture and runoff variability in vineyards under different rainfall distributions in a Mediterranean climate and its influence on crop productivity. Journal of Hydrology 321, 131-146. http:// doi.org/10.1016/j.jhydrol.2005.07.055.

Ramos, M.C., Martínez-Casasnovas, J.A. 2007. Soil loss and soil water content affected by land levelling in Penedès vineyards, NE Spain. Catena 71, 210-217. http://doi.org/10.1016/j. catena.2007.03.001.

Reinecke, A.J., Albertus, R.M.C., Reinecke, S.A., Larink, O. 2008. The effects of organic and conventional management practices on feeding activity of soil organisms in vineyards. African Zoology 43, 66-74. http://doi.org/10.1080/15627020.2008.11407408.

Reiter, P., Gutjahr, O., Schefczyk, L., Heinemann, G., Casper, M. 2016. Bias correction of ENSEMBLES precipitation data with focus on the effect of the length of the calibration period. Meteorologische Zeitschrift 25, 85-96. http://doi.org/10.1127/metz/2015/0714.

Richter, G. 1980. On the soil erosion problem in the temperate humid Area of Central Europe. GeoJournal 4, 279-287. 
Rodrigo Comino, J., Brings, C., Lassu, T., Iserloh, T., Senciales, J., Martínez Murillo, J., Ruiz Sinoga, J., Seeger, M., Ries, J. 2015. Rainfall and human activity impacts on soil losses and rill erosion in vineyards (Ruwer Valley, Germany). Solid Earth 6, 823-837. http://doi. org/10.5194/se-6-823-2015.

Rodrigo Comino, J., Iserloh, T., Lassu, T., Cerdà, A., Keestra, S.D., Prosdocimi, M., Brings, C., Marzen, M., Ramos, M.C., Senciales, J.M., Ruiz Sinoga, J.D., Seeger, M., Ries, J.B., 2016a. Quantitative comparison of initial soil erosion processes and runoff generation in Spanish and German vineyards. Science of the Total Environment 565, 1165-1174. http://doi. org/10.1016/j.scitotenv.2016.05.163.

Rodrigo Comino, J., Iserloh, T., Morvan, X., Malam Issa, O., Naisse, C., Keesstra, S.D., Cerdà, A., Prosdocimi, M., Arnáez, J., Lasanta, T., Ramos, M.C., Marqués, M.J., Ruiz Colmenero, M., Bienes, R., Ruiz Sinoga, J.D., Seeger, M., Ries, J.B. 2016b. Soil erosion processes in European vineyards: A qualitative comparison of rainfall simulation measurements in Germany, Spain and France. Hydrology 3, 6. http://doi.org/10.3390/hydrology3010006.

Rodrigo Comino, J., Quiquerez, A., Follain, S., Raclot, D., Le Bissonnais, Y., Casalí, J., Giménez, R., Cerdà, A., Keesstra, S.D., Brevik, E.C., Pereira, P., Senciales, J.M., Seeger, M., Ruiz Sinoga, J.D., Ries, J.B. 2016c. Soil erosion in sloping vineyards assessed by using botanical indicators and sediment collectors in the Ruwer-Mosel Valley. Agriculture, Ecosystems and Environment 233, 158-170. http://doi.org/10.1016/j.agee.2016.09.009.

Rodrigo Comino, J., Ruiz Sinoga, J.D., Senciales González, J.M., Guerra-Merchán, A., Seeger, M., Ries, J.B. 2016d. High variability of soil erosion and hydrological processes in Mediterranean hillslope vineyards (Montes de Málaga, Spain). Catena 145, 274-284. http:// doi.org/10.1016/j.catena.2016.06.012.

Rodrigo-Comino, J, Seeger, M., Senciales González, J.M., Ruiz Sinoga, J.D., Ries, J.B. 2016e. Variación espacio-temporal de los procesos hidrológicos del suelo en viñedos con elevadas pendientes (valle del Ruwer-Mosela, Alemania). Cuadernos de Investigación Geográfica 42 (1), 281-306. http://doi.org/10.18172/cig.2934.

Ruiz-Colmenero, M., Bienes, R., Marques, M.J. 2011. Soil and water conservation dilemmas associated with the use of green cover in steep vineyards. Soil and Tillage Research 117, 211-223. http://doi.org/10.1016/j.still.2011.10.004.

Ruiz-Colmenero, M., Bienes, R., Eldridge, D.J., Marques, M.J. 2013. Vegetation cover reduces erosion and enhances soil organic carbon in a vineyard in the central Spain. Catena 104, 153 160. http://doi.org/10.1016/j.catena.2012.11.007.

Rüttimann, M., Prasuhn, V. 1993. Feldmessgerät zur Erfassung von flächenhafter Bodenerosion und Stofffrachten aus Maisflächen. Zeitschrift für Kulturtechnik und Landentwicklung 34, 338-348.

Rüttimann, M., Schaub, D., Prasuhn, V., Rüegg, W. 1995. Measurement of runoff and soil erosion on regularly cultivated fields in Switzerland - some critical considerations. Catena 25, 127 139. http://doi.org/10.1016/0341-8162(95)00005-D.

Saleh, A. 1993. Soil roughness measurement: Chain method. Journal of Soil and Water Conservation 48, 527-529.

Sastre, B., Barbero-Sierra, C., Bienes, R., Marques, M.J., García-Díaz, A. 2016. Soil loss in an olive grove in Central Spain under cover crops and tillage treatments, and farmer perceptions. Journal of Soils and Sediments 1-16. http://doi.org/10.1007/s11368-016-1589-9.

Seeger, M. 2007. Uncertainty of factors determining runoff and erosion processes as quantified by rainfall simulations. Catena 71, 56-67. http://doi.org/10.1016/j.catena.2006.10.005.

Simonson, R.W. 1959. Outline of a generalized theory of soil genesis. Soil Science Society of America Proceedings 23, 152-156. 
Smith, P., Cotrufo, M.F., Rumpel, C., Paustian, K., Kuikman, P.J., Elliott, J.A., McDowell, R., Griffiths, R.I., Asakawa, S., Bustamante, M., House, J.I., Sobocká, J., Harper, R., Pan, G., West, P.C., Gerber, J.S., Clark, J.M., Adhya, T., Scholes, R.J., Scholes, M.C. 2015. Biogeochemical cycles and biodiversity as key drivers of ecosystem services provided by soils. SOIL 1, 665-685. http://doi.org/10.5194/soil-1-665-2015.

Stigter, C.J. 1984. Mulching as a traditional method of microclimate management. Archives of Meteorology, Geophysics and Bioclimatology B 35, 147-154.

Tarolli, P. 2016. Humans and the Earth's surface. Earth Surface Processes and Landforms 41, 2301-2304. http://doi.org/10.1002/esp.4059.

Tarolli, P., Sofia, G. 2016. Human topographic signatures and derived geomorphic processes across landscapes. Geomorphology 255, 140-161. http://doi.org/10.1016/j.geomorph.2015.12.007.

Xiao, L., Hu, Y., Greenwood, P., Kuhn, N.J. 2015. A combined raindrop aggregate destruction testsettling tube (RADT-ST) approach to identify the settling velocity of sediment. Hydrology 2, 176. http://doi.org/10.3390/hydrology2040176. 